\title{
Poland
}

\section{Science planning praised - but improvements still needed}

SCIENCE planners and civil servants in the science-related ministries should improve their scientific qualifications, according to the "guidelines" for the Eighth Congress of the Polish United Workers' Party this week.

The "guidelines", which after due 1981-85 Five Year Plan, initially paint a glowing picture of successes scored by Poland's special approach to science planning, with its hierarchical structure of research tasks, from "Government" and "Key" down to "Departmental", problems. These achievements range from laser thermonuclear microsynthesis to mining tectonics, the mapping of Poland's flora and fauna, and the use of "Arctic Marine organisms"' (ie krill) as a source of protein.

But it does seem that the "problem solving" structure of Polish research has not yet overcome the difficulty endemic throughout the Comecon bloc - that of implementing $\mathbf{R} \& \mathbf{D}$ results.

"It is absolutely necessary", say the guidelines "to introduce a system enabling universal incorporation of Polish inventions in national research and development endeavours. Contacts and cooperation among scientists, engineers and workers must be strengthened as an important vehicle of propagating technical progress and enriching the scope of innovations in industrial plants."

When it comes to the details of research planning, however, the "guidelines" show a certain ambivalence. On the one hand "the realisation of long-range research plans requires their closer connection to discussion will form the basis for the

development programmes of the corresponding fields of the national economy". On the other, "more flexible methods of work must be developed in scientific as well as research and development units", and "the manner in which scientific research establishments are organised, their employment structure and planning methods, must be adjusted to changing needs."

To enable them to strike the proper balance between these demands, the staff of the relevant ministries are urged to continue their higher education "in cooperation with the institutes of the Polish Academy of Sciences and university-related schools".

The "guidelines" propose a number of "tasks" for the special attention of the science and technology planners. These come as no surprise, either within a world context (limitation of petroleum consumption, development of "unconventional" energy sources, and environmental protection) or within the special conditions of Poland (water management, development of high-protein and oleaginous plants, the development of specialised exports to the highly developed countries, and the export of Polish technical know-how).

But perhaps the most interesting "task" is "the production of pharmaceuticals . . . through the more extensive use of domestic syntheses and achievements in the field of genetics", a field in which, according to a recent article in Polityka, the commercial breakthrough point may be expected in the near future.

Vera Rich

\section{United Kingdom}

\section{Study finds malnutrition in $\mathbf{7 \%}$ of elderly}

NUTRITIONAL problems among Britain's elderly population are highlighted in a report* published recently. "Nutrition and Health in Old Age", is the result of a survey of the nutritional status of 365 old people in 1972-73. The incidence of malnutrition was $26 \mathbf{( 7 \% )}$. It was twice as common in subjects over 80 years old.

Malnutrition was associated with both medical and social risk factors. Medical conditions included chronic bronchitis, dementia, depression, difficulty in swallowing, and poor dentition. The social risk factors included being housebound, living alone without regular cooked meals,
The Netherlands

\section{Recombinant DNA research thrives}

RECOMBINANT DNA research in The Netherlands is expanding at a rapid rate. At the end of 1976 only seven projects at universities had been registered by the commission of experts, established by the Royal Academy of Sciences in 1975 to look at genetic manipulation. By the end of 1979 , there were 78 such projects, of which about 10 are with industrial companies, such as Unilever Research. All this research, according to the commission's latest annual report just published, will take place in category I and II laboratories.

The work of the Academy's commission has now been taken over by a government commission whose members include representatives of trade unions, the health authorities and industry. The Academy commission relaxed the safety guidelines in 1978. These came into effect a year ago and were extended to include yeast as a host organism. The new commission has already announced that it will consider a further relaxation of the regulations.

The chairman of the first commission in a farewell speech - emphasised the need to build a category III facility which researchers say is needed in the country. The lack of such a laboratory has resulted in a falling behind in important research on, for example, cancer-inducing viruses and genetic aberrations, fields in which until recently The Netherlands had made progress. Even with a further relaxation of the regulations, Dutch scientists say that a category III laboratory is essential for research using DNA of warm-blooded animals and, in particular, man.

The previously strict rules in the country did not result in the departure of Dutch scientists to work abroad. Only seven researchers left temporarily to work in a category II or III facility, and five of them also asked foreign laboratories to work for them. But, in its last report, the commission says that it would be wrong to conclude that molecular biological research in The Netherlands had not suffered from the strict guidelines in force until recently.

In The Netherlands, especially in industrial circles, there is still a lot of dissatisfaction about the conditions in which molecular biologists must work. The public debate which reached a peak in June 1978 has now died down, and among scientists there is very little opposition to the relaxing of the guidelines. A longawaited special committee to study the ethics and social aspects of work with genetic material has still not been set up by the Dutch government, but this is expected soon.

Casper Schuuring 